\title{
Exploring the Theatrical Experience: Results From an Empirical Investigation
}

\author{
Sabine Boerner, Johanna Jobst, and Meike Wiemann \\ University of Konstanz
}

\begin{abstract}
The article aims at explaining visitors' overall judgment of a theatrical event. A questionnaire was constructed including the 4 dimensions of the theatrical experience identified by Eversmann (2004): perceptual, cognitive, emotional, and communicative. The authors investigated 125 visitors of a production in a German community theater and confirmed that both the emotional and cognitive dimensions were determinants of visitors' overall judgment of a theatrical event. Implications for further research on the theatrical experience are discussed.
\end{abstract}

Keywords: empirical study, reception research, theatrical event, theatrical experience

Theorists agree with practitioners (i.e., actors, directors, and theater managers) that performances in theater are explicitly made to address the audience (e.g., Martin \& Sauter, 1995; Sauter, 2000). In theater, as with other forms of performing arts, the spectator is an essential part of the performance (e.g., Bentley, 1966; Eversmann, 2004). Hence, the most obvious way to evaluate the success of a theatrical performance is to explore the reception of the visitors; however, it is surprising that studies on audience reception in theater are still rare (Schoenmakers \& Tulloch, 2004; Scollen, 2008). Two lines of research can be distinguished when reviewing empirical approaches to exploring audience reception in theater.

First, some studies explore the content of the theatrical experience. Some of those are dedicated to the perception of selected aspects of the theatrical performance. For example, Perky (1976) suggested a scale for the assessment of performers' quality, which has been further elaborated by Konijn (1991). Other studies try to identify the full range of components that might determine visitors' overall judgment of a theatrical performance. Pavis (1988) developed criteria for a semiotic expert analysis of theatrical performances (e.g., lighting, stage set) in the context of education. Sauter, Kalvik, and Isaksson (1986) suggested an instrument to cover the elements that spectators perceive during a performance (e.g., topic of the play, ensemble, music, stage design). However, because the content of the theatrical experience may vary from play to play and from performance to performance, these approaches may not be adequate to formulate general statements about the determinants of visitors' overall judgment (Eversmann, 2004).

Second, some studies focus on similarities of the structure of the theatrical event in the eyes of the spectator. For example, Sauter and colleagues identified four segments of the theatrical event, that

Sabine Boerner, Johanna Jobst, and Meike Wiemann, Department of Politics and Management, University of Konstanz, Germany.

Correspondence concerning this article should be addressed to Sabine Boerner, University of Konstanz, PO Box 88, 78457 Konstanz, Germany. E-mail: sabine.boerner@uni-konstanz.de is, playing culture, cultural context, cultural theatricality, and theatrical playing (Martin \& Sauter, 1995; Sauter, 2000, 2002). By contrast, studies by Konijn $(1991,1999)$ focused on spectators' emotions during a performance. The most recent study in this research line has been conducted by Eversmann (2004). On the basis of qualitative interviews with theatergoers, he identified four dimensions of visitors' experience of the theatrical event, namely, the perceptive, cognitive, emotional, and communicative dimensions. Each dimension is defined by visitors' reactions to the particular performance under study. Compared with content aspects (see above), these structural dimensions of the theatrical experience are more likely to be found across all kinds of different theater plays and performances. The resulting model thus can easily be generalized to visitors' experience in theater. Still, to date, structural approaches have never been applied to predict visitors' overall judgments of a theatrical experience.

Against this background, the present study made an empirical effort to identify the determinants of visitors' overall judgment of a theatrical event, thereby relying on the structural instead of the content approach. More precisely, Eversmann's (2004) approach was used to answer the following question: Which aspects of the theatrical experience contribute to visitors' overall judgments of a theatrical event? The contribution of this reasearch to the extant literature is thus threefold. First, it enlarges the small body of empirical research on visitors' perception in theater, trying to explain visitors' overall judgment by structural instead of content determinants. Second, by developing and testing measures for the structural dimensions suggested by Eversmann (2004), our study can be interpreted as the first quantitative follow-up of Eversmann's qualitative study. The empirical investigation of 125 visitors of a German community theater provides first insights in the degree to which Eversmann's structural dimensions contribute to the overall judgment in theater. Third, our study may inspire further research on reception in the performing arts. By applying the instrument developed in our study to other plays and performances, it can be tested whether and to what degree Eversmann's concept can be generalized to the theatrical experience. Moreover, by further adapting our instrument, the validity of Eversmann's concept can be tested in other forms of performing arts, such as 
opera, musical, or concert. Taken together, findings expected from future research will reveal whether the parallels that Eversmann discovered in the structural dimensions of aesthetical experience in both visual art and theater performances can be generalized.

The article proceeds as follows. In the first step, Eversmann's (2004) approach is described. In the second step, measures for the dimensions of the theatrical event and their subdivisions as suggested by Eversmann are developed. Third, an empirical investigation is described to identify the determinants of visitors' overall judgment of a theatrical performance. Fourth, the results of the empirical study are discussed, limitations of the present study are described, and implications for further research on audience reception in theater are presented.

\section{The Experience of the Theatrical Event: Eversmann's (2004) Approach}

Eversmann's (2004) aim was to discover "what spectators of theater performances experience" (p. 139). Inspired by Csikszentmihalyi and Robinson's (1990) research on the aesthetic experience of art experts working in museums, he decided to focus on the structure instead of the content of the theatrical experience. On the basis of semistructured interviews, Eversmann identified four structural dimensions of the theatrical experience, namely, the perceptual, cognitive, emotional, and communicative dimensions (see Figure 1). Each of these dimensions is further described by three or four subdivisions, which are partly illustrated by quotations from the interviews.

The perceptual dimension is defined as "the perception per se" (Eversmann, 2004, p. 151), that is, the visitor's pure experience of impulses from the stage without any interpretation of the stimuli. The first subdivision of this dimension is the spectator's first and spontaneous reaction to all kinds of stimuli presented in a perfor-

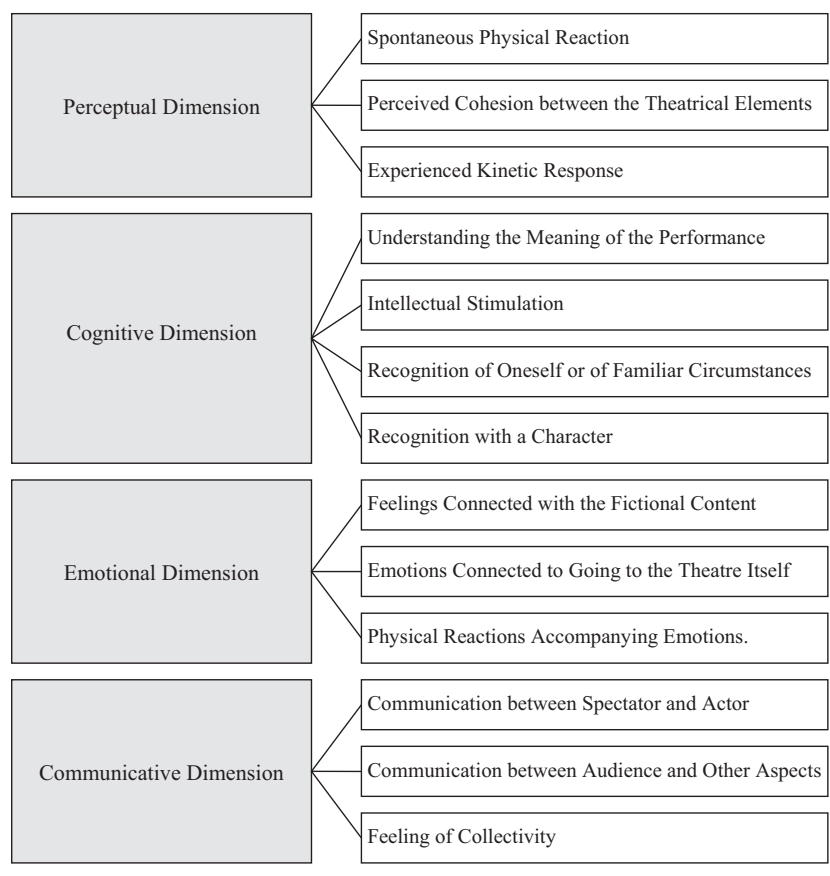

Figure 1. Dimensions and subdivisions of the theatrical experience. mance, such as visual, auditory, or haptic. Second, spectators perceive the degree of synergy or cohesion among these stimuli. Following Eversmann's (2004) findings, spectators appreciate a high level of cohesion. The third perceptual subdivision includes the kinetic responses to the stimuli that spectators may experience. For example, when intensively watching an actor's movements, a spectator may experience (latent) muscle impulses giving the impression of these same movements. Although the spectator only imagines copying these movements, he or she gains some idea "of what the actor is going through" (Eversmann, 2004, p. 152).

The cognitive dimension covers the spectator's intellectual dealing with a performance, which is influenced by both general and theater-specific knowledge and personal expectations. First, the spectator tries to understand the meaning of the performance, searching for a coherent interpretation of the performance as a whole. The second subdivision is intellectual stimulation. The performance is experienced as a source of inspiration, either by providing new insights and thoughts or by raising questions that can linger in the spectator's memory for a long time. The third subdivision of the spectator's mental reaction is the recognition of himself/herself or familiar circumstances in the performance. In most cases, the recognition is with the main character of the play. However, the main source of recognition does not lie in personal characteristics such as age, gender, or race, but in the spectator's comparison of a character's situation with his or her own. The last cognitive subdivision is the spectator's recognition with a character. Instead of comparing his or her real situation with an actor's situation on stage (see above), the spectator imagines to be in the same situation like the character in the play. He or she compares the character's reactions to his or her own imagined reactions ("What would I do if I were in the same situation as the fictional character?" Eversmann, 2004, p. 154).

The emotional dimension includes spectators' affective reactions to the performance. The first subdivision covers feelings connected with the fictional content of the performance. This subdivision includes both the same feelings the characters on stage are believed to have and the spectator's presumed feelings toward the characters when encountering them in real life. The second subdivision consists of emotions connected to going to the theater itself. These emotions are closely related to the experience of flow (Csikszentmihalyi, 1991), that is, "the feeling of being carried away by the performance, of losing oneself in the world of the stage, of forgetting everyday reality" (Eversmann, 2004, p. 155). The third subdivision includes the physical components of the spectator's emotions, such as laughing, crying, or being breathless.

The communicative dimension deals with the interaction between performance and spectators. First, communication happens between the individual spectator and the individual actor. Following Eversmann (2004), "the live presence of the actor is the essential formative element of theater" (p. 157). Second, there is communication between the audience and other aspects of the play, such as the director or the playwright. Third, communication happens within the audience in a theater, which may result in a feeling of communality among the spectators.

As mentioned above, Eversmann's (2004) aim was to discover structural dimensions of the theatrical experience. When applying his approach to our research goal, namely, to predict visitors' overall judgment of a theatrical event, we made some considerations. First, Eversmann (2004) argued that theatrical events and 
individual reactions to them are too heterogeneous to be considered in a generalized way. He therefore considered "the" theatrical experience to be an inadequate research object. Instead, inspired by Csikszentmihalyi and Robinson (1990), he focused on so-called theatrical peak experiences, that is, "performances that are highly evaluated by the individual" (Eversmann, p. 139). He defined those peak experiences as experiences of flow (Csikszentmihalyi, 1991). Spectators are fully concentrated, all their attention is focused on the stage, they are completely wrapped in and carried along by the performance, loosing sense of time, and forgetting everyday worries. In contrast, our empirical study addressed the theatrical experience in general.

Second, Eversmann (2004) involved theater professionals in his empirical study, assuming that these people are particularly susceptible to aesthetic experiences and quite conscious of their own reactions toward performances. Moreover, they were expected to have the ability to articulate their own experience and to be well trained in the explicit and implicit rules and conventions of watching theater. However, recognizing the potential disadvantages of this sample, Eversmann complemented the interviews with written accounts of freshman students in theater studies. Nevertheless, his sample still can be considered an expert sample. In contrast, our study explored the overall judgment of a general theater audience.

\section{Method}

\section{Developing Measures}

Independent variables. Because this was the first quantitative study based on Eversmann's (2004) conception, a questionnaire had to be developed for the purpose of the study. Each of the four dimensions was defined as a single construct, split into the subdivisions according to Eversmann's description. The perceptual dimension was defined as including (a) the spectator's spontaneous physical reaction, (b) his or her perceived cohesion between the theatrical elements, and (c) the experienced kinetic response. The cognitive dimension consisted of (a) understanding the meaning of the performance, (b) intellectual stimulation, (c) recognition of oneself or familiar circumstances, and (d) recognition with a character. The emotional dimension included (a) feelings connected to the fictional content of the performance, (b) feelings connected to going to the theater itself, and (c) physical reactions accompanying emotions. The communicative dimension split in three subdivisions, namely, (a) communication between spectator and actor, (b) communication between spectator and other aspects of the play, and (c) feeling of collectivity.

Following Eversmann (2004), we defined each subdivision by the visitors' reactions to the particular content elements of the performance under study. To operationalize these subdivisions, we thus had to link them with the content of the performance. We therefore directly referred to single aspects such as the characters' particular situation (see Item 32; Table 1), the plot (see, e.g., Items 6 and 15), or the acoustical and visual effects of the performance (see, e.g., Items 2 and 3). Moreover, to present the statements as concretely as possible, we directly related some of the items to the performance (i.e., The Dawns Here Are Quiet) used in the study (see, e.g., Items 1, 9, and 10). In sum, for each subdivision, we formulated three to six items (see Table 1).
Dependent variable. The visitors' overall judgment of the theatrical event was measured by a multi-item scale. Because there is no validated instrument in the literature, we developed an eight-item scale guided by measurements developed and validated by Renz (2006) and Jobst (2007) in the context of opera. The items of this scale are described in Table 1.

Similar to research on reception in music theater (e.g., Boerner \& Jobst, 2008), we used 5-point Likert scales, with 1 indicating the lowest (strongly disagree) and 5 indicating the greatest agreement (strongly agree). In addition, a neutral option was offered (I don't know). To avoid errors of judgment such as the "halo effect" (Thorndike, 1920), we did not present the items according to their relative constructs but in a random order (Johnson \& Vidulich, 1956). This design allows for a more severe test of the scale reliability, which is particularly relevant for newly developed measures.

Controls. Because visitors' expectations may influence their evaluation of a theatrical event (Boorsma \& van Maanen, 2003; DiMaggio, Useem, \& Brown, 1978; Sauter, 2002; Thompson, 2006), we included variables that may affect expectations as controls. Accordingly, we surveyed participants' age, gender, and educational attainment. In addition, we included their prior experience in theater, asking for their level of expertise in theater and their knowledge of the performed play.

Before being applied in the final sample, the questionnaire was evaluated by two visitors of a previous performance of the The Dawns Here Are Quiet. These visitors were asked to evaluate the comprehensibility, clearness, order, and length of the questions as well as the duration of and their individual impact of participating in the study. According to the results of this pretest, some items were reformulated to enhance clearness and to avoid ambiguity, and other items were cancelled because of redundancy.

\section{Empirical Study}

Sample. The study was conducted in 2008 during two live performances of a play by Boris Wassiljew from 1969 (The Dawns Here Are Quiet) in a medium-size German community theater. ${ }^{1}$ When visitors entered the theater, they were handed a flier announcing the study and promising a free drink in case of their participation. After the performance, all visitors were personally asked for their participation and handed the questionnaire. In total, 126 questionnaires were completed after both performances, resulting in a response rate of $38.3 \%$ (Performance 1: $n=79$; Performance 2: $n=47$ ). In comparison to similar surveys (Reuband, 2005) and considering the time restrictions when collecting data in theaters (Roose, Waege, \& Agneessens, 2003), this can be seen as an acceptable value. One questionnaire was excluded because of limited data quality (missing values $>30 \%$ in scale items), resulting in a final sample of 125 visitors. Participants were predominantly women (56\%), 50 years of age on average, and highly educated $(54 \%$ of the participants held a university diploma; 19\% had A levels). Hence, our sample was representative of a typical theater audience (Sargeant, 1997). Although most of the participants were frequent theatergoers $(62 \%)$ or "laymen with

\footnotetext{
${ }^{1}$ German title "Im Morgengrauen ist es noch still ..."; Stadtheater Konstanz; Director Martin Nimz.
} 
Table 1

Constructs and Items

\begin{tabular}{|c|c|}
\hline Dimension and subdivision & Item \\
\hline \multicolumn{2}{|l|}{ Perceptual dimension } \\
\hline \multirow[t]{3}{*}{ Spontaneous physical reaction } & 1. I was very much frightened by the glaring flashes and the noise of bombs. \\
\hline & 2. Some of the effects were really inappropriate. \\
\hline & 3. I felt directly affected by some of the effects that were used in the production. \\
\hline \multirow[t]{4}{*}{ Perceived cohesion between the theatrical elements } & 4. The background music harmonized very well with the actors' play. \\
\hline & 5. The effects used in this production were very successful and well balanced. \\
\hline & 6. The plot was well supported by the stage design and the stage props. \\
\hline & 7. The bomb attack was well put on stage by glaring flashes and the noise of explosion. \\
\hline \multirow[t]{3}{*}{ Experienced kinetic response } & $\begin{array}{l}\text { 8. When everybody on stage was silent in order not to be discovered by the enemy, my } \\
\text { body was also paralyzed. }\end{array}$ \\
\hline & 9. When the interpreter was being stabbed to death, I felt uncomfortable myself. \\
\hline & $\begin{array}{l}\text { 10. When the ill "doctor's daughter" tried to avoid Waskow's medicine, I myself felt } \\
\text { struggling. }\end{array}$ \\
\hline \multicolumn{2}{|l|}{ Cognitive dimension } \\
\hline \multirow[t]{6}{*}{ Understanding the meaning of the performance } & 11. Some scenes didn't make any sense to me. ${ }^{a}$ \\
\hline & 12. In my eyes, the production was very coherent. \\
\hline & 13. For me, the production was clearly comprehensible. \\
\hline & 14. I was able to understand every scene and its meaning in the context of the play. \\
\hline & 15. I was very well able to follow the plot of the play. \\
\hline & 16. In my eyes, the production was completely dissonant. ${ }^{a}$ \\
\hline \multirow[t]{3}{*}{ Intellectual stimulation } & 17. I received many thought-provoking impulses from the production. \\
\hline & 18. For me, visiting this performance was a personal gain. \\
\hline & 19. For me, the performance was very thought provoking. \\
\hline \multirow[t]{3}{*}{ Recognition of oneself or of familiar circumstances } & 20. Some aspects of the performance reminded me of anecdotes told by friends or relatives. \\
\hline & 21. Some scenes reminded me of personal problems. \\
\hline & 22. I compared the character's situation on stage with situations in my life. \\
\hline \multirow[t]{2}{*}{ Recognition with a character } & $\begin{array}{l}\text { 23. Sometimes, I was deliberating what I would have probably done in lieu of the } \\
\text { characters in the play. }\end{array}$ \\
\hline & $\begin{array}{l}\text { 24. I was asking myself questions like "Would I have been going voluntarily to the front in } \\
\text { the place of the women?" or "What would I have been doing in the place of Waskow?' } \\
\text { 25. At times, I put myself in the characters' position. }\end{array}$ \\
\hline \multicolumn{2}{|l|}{ Emotional dimension } \\
\hline \multirow[t]{3}{*}{ Feelings connected to the fictional content } & 26. The fictional content of the play did not touch me at all. ${ }^{\mathrm{a}}$ \\
\hline & 27. I was very much affected by the women's individual destinies. \\
\hline & 28. I was very much concerned about some sequences. \\
\hline \multirow[t]{3}{*}{ Emotions connected to going to the theater itself } & 29. Today, going to theater was very special for me. \\
\hline & 30. Today's theater experience was really interesting. \\
\hline & 31. Today's theater experience was really exciting. \\
\hline \multirow[t]{3}{*}{ Physical reactions } & 32. During some sequences, my heart almost stopped beating. \\
\hline & 33. Sometimes, I clutched the arms of my seat. \\
\hline & 34. During some sequences, I felt paralyzed for some instances. \\
\hline \multicolumn{2}{|l|}{ Communicative dimension } \\
\hline \multirow[t]{3}{*}{ Communication between spectator and actor } & $\begin{array}{l}\text { 35. At the end of the play, when the women were talking about their lives, I felt personally } \\
\text { addressed. }\end{array}$ \\
\hline & 36. I felt that my reactions directly affected the characters and their actions. \\
\hline & 37. During the interview with the last soldier I felt personally addressed. \\
\hline \multirow{3}{*}{$\begin{array}{l}\text { Communication between audience and other } \\
\text { aspects of the play }\end{array}$} & 38. The audience responded concertedly to the actions on stage. \\
\hline & 39. There was communication between the production and the audience as a collective. \\
\hline & 40. The production established a direct contact between the audience and the actors. \\
\hline \multirow[t]{3}{*}{ Feelings of collectivity } & 41. I had the feeling of being part of the audience facing the actors on stage. \\
\hline & $\begin{array}{l}\text { 42. Since the spectators reacted concertedly and in a similar way, I was feeling a sense of } \\
\text { community. }\end{array}$ \\
\hline & $\begin{array}{l}\text { 43. During the performance, I felt somehow associated with other members of the } \\
\text { audience. }\end{array}$ \\
\hline \multirow[t]{8}{*}{ Overall judgment of the theatrical event } & \\
\hline & 44. Altogether, this was a high-quality production. \\
\hline & 45. I was totally enthusiastic about the performance. \\
\hline & 46. It would be a mistake to remove this production from the seasonal program. \\
\hline & 47. Altogether, the performance was inspiring and never boring. \\
\hline & 48. The performance met my expectations completely. \\
\hline & 49. In my eyes, the production is a flop. ${ }^{a}$ \\
\hline & $\begin{array}{l}\text { 50. I am sure to remember the positive impression of this performance for a long time. } \\
\text { 51. In my eyes, this production was pure waste of time. }\end{array}$ \\
\hline
\end{tabular}

\footnotetext{
${ }^{\text {a }}$ Reversed-scored.
} 
Table 2

Intercorrelations Between the Constructs and Reliabilities (Subdivisions)

\begin{tabular}{|c|c|c|c|c|c|c|c|c|c|c|c|c|c|c|}
\hline Scale & 1 & 2 & 3 & 4 & 5 & 6 & 7 & 8 & 9 & 10 & 11 & 12 & 13 & 14 \\
\hline \multicolumn{15}{|c|}{ Perceptual dimension } \\
\hline 1 & $(.44)$ & & & & & & & & & & & & & \\
\hline 2 & $.44^{* *}$ & $(.75)$ & & & & & & & & & & & & \\
\hline 3 & $.34^{* *}$ & $.36^{* *}$ & (.66) & & & & & & & & & & & \\
\hline \multicolumn{15}{|c|}{ Cognitive dimension } \\
\hline 4 & $.46^{* *}$ & $.69^{* *}$ & $.25^{* * *}$ & $(.88)$ & & & & & & & & & & \\
\hline 5 & $.39^{* *}$ & $.60^{* *}$ & $.50^{* * *}$ & $.66^{* *}$ & $(.80)$ & & & & & & & & & \\
\hline 6 & .07 & $.29^{* *}$ & $.41^{* * *}$ & $.21^{*}$ & $.41^{* * *}$ & $(.69)$ & & & & & & & & \\
\hline 7 & .11 & $.25^{* *}$ & $.57^{* * *}$ & $.25^{* *}$ & $.53^{* * *}$ & $.51^{* *}$ & $(.75)$ & & & & & & & \\
\hline \multicolumn{15}{|c|}{ Emotional dimension } \\
\hline 8 & $.44^{* *}$ & $.55^{* *}$ & $.55^{* *}$ & $.52^{* *}$ & $.62^{* *}$ & $.35^{* *}$ & $.39^{* * *}$ & $(.80)$ & & & & & & \\
\hline 9 & $.43^{* *}$ & $.71^{* *}$ & $.44^{* * *}$ & $.68^{* *}$ & $.77^{* * *}$ & $.32^{* *}$ & $.36^{* *}$ & $.60^{* * *}$ & $(.84)$ & & & & & \\
\hline 10 & $.41^{* *}$ & $.41^{* *}$ & $.69^{* *}$ & $.27^{* * *}$ & $.53^{* * *}$ & $.36^{* *}$ & $.44^{* *}$ & $.56^{* * *}$ & $.48^{* *}$ & $(.77)$ & & & & \\
\hline \multicolumn{15}{|c|}{ Communicative dimension } \\
\hline 11 & $.31^{* *}$ & $.22^{*}$ & $.58^{* * *}$ & $.20^{*}$ & $.50^{* * *}$ & $.39^{* *}$ & $.55^{* *}$ & $.44^{* *}$ & $.34^{* * *}$ & $.47^{* *}$ & $(.75)$ & & & \\
\hline 12 & $.30^{* *}$ & $.53^{* *}$ & $.46^{* *}$ & $.45^{\text {** }}$ & $.49^{* *}$ & $.42^{* * *}$ & $.37^{* *}$ & $.36^{* *}$ & $.49^{* * *}$ & $.32^{* * *}$ & $.42^{* *}$ & (.79) & & \\
\hline 13 & $.33^{* *}$ & $.31^{* *}$ & $.54^{* * *}$ & $.20^{*}$ & $.41^{* *}$ & $.36^{* *}$ & $.47^{* *}$ & $.33^{* *}$ & $.34^{* * *}$ & $.46^{* *}$ & $.50^{* * *}$ & $.64^{* * *}$ & $(.59)$ & \\
\hline \multicolumn{15}{|c|}{$\begin{array}{l}\text { Overall judgment of the } \\
\text { theatrical event }\end{array}$} \\
\hline 14 & $.53^{* *}$ & $.68^{* *}$ & $.43^{* * *}$ & $.73^{* * *}$ & $.79^{* * *}$ & $.32^{* * *}$ & $.36^{* *}$ & $.62^{* * *}$ & $.86^{* * *}$ & $.48^{* *}$ & $.39^{* * *}$ & $.50^{* * *}$ & $.40^{* * *}$ & $(.95)$ \\
\hline
\end{tabular}

Note. Reliabilities (Cronbach's alpha) shown on the diagonal within parentheses. $1=$ spontaneous physical reaction; $2=$ perceived cohesion between the theatrical elements; $3=$ experienced kinetic response; $4=$ understanding the meaning of the performance; $5=$ intellectual stimulation; $6=$ recognition of oneself or of familiar circumstances; $7=$ recognition with a character; $8=$ feelings connected with fictional content; $9=$ emotions connected to going to the theater itself; $10=$ physical reactions; $11=$ communication between spectator and actor; $12=$ communication between audience and other aspects of the play; $13=$ feelings of collectivity; $14=$ overall judgment.

* $p \leq .05$. *** $p \leq .01$.

some experience" (28\%), the majority $(82 \%)$ did not know the play before.

Preliminary analyses. Prior to the main data analyses, items with more than $30 \%$ missing values were excluded from the sample. The remaining missing values were imputed using the expectationmaximization algorithm. Although being one of the recommended methods for preventing biases caused by not completely random missing data (Allison, 2001; Schafer \& Graham, 2002), the algorithm estimates missing data by using an iterative maximum-likelihood procedure (Zwingmann, Wirtz, Mueller, Koerber, \& Murken, 2006). The imputation was conducted with the software NORM (Graham, Cumsille, \& Elek-Fisk, 2003).

For most of the subdivisions, Cronbach's alphas were above .70, showing sufficient reliability (see Table 2). However, the subdivisions "recognition of oneself or of familiar circumstances" (cognitive dimension) and "the spectator's experienced kinetic response" (perceptual dimension) shortly failed the .70 value. In addition, the subdivisions "the spectator's spontaneous physical reaction" (perceptual dimension) and "feeling of collectivity" (communicative dimension) could not be measured with sufficient reliability.

To assess the measurement validity of the constructs of visitors' perception, we ran confirmatory factor analyses (CFAs) with AMOS 17.0 (Arbuckle \& Wothke, 2003). Given that the ratio of the number of cases to the number of free parameters is recommended to be 20:1 or, at least, 10:1 to run precise CFA (Kline, 2005), our sample did not allow for a comprehensive test of all four dimensions. Instead, separate analyses were run for each dimension, that is, perceptual, cognitive, emotional, and communicative. Whereas the models measuring the cognitive and the emotional dimension as well as the overall judgment reached good global fit, the perceptual and the communicative dimension models showed only poor agreement with the empirical data (see Table 3 ). The chi-square value revealed significant differences between the empirical and the model-implied covariances. In addition, the comparative fit index as well as the normed fit index and TuckerLewis index fell below the threshold.

Table 3

Measures of Global Fit for the Models (Confirmatory Factor Analyses)

\begin{tabular}{|c|c|c|c|c|c|c|c|c|}
\hline Scale & $\chi^{2}$ & $d f$ & $p$ & $\chi^{2} / d f$ & NFI & TLI & CFI & RMSEA \\
\hline Perceptual dimension & 84.94 & 32 & .00 & 2.65 & .74 & .73 & .81 & .12 \\
\hline Cognitive dimension & 133.65 & 84 & .00 & 1.59 & .87 & .93 & .95 & .07 \\
\hline Emotional dimension & 48.04 & 24 & .00 & 2.00 & .91 & .93 & .95 & .09 \\
\hline Communicative dimension & 86.87 & 24 & .00 & 3.62 & .80 & .76 & .84 & .15 \\
\hline Overall judgment & 45.32 & 20 & .00 & 2.27 & .95 & .96 & .97 & .10 \\
\hline
\end{tabular}

Note. $\quad \mathrm{NFI}=$ normed fit index; TLI $=$ Tucker-Lewis index; CFI $=$ comparative fit index; RMSEA $=$ root-mean-square error of approximation. 
Table 4

Measures of Global Fit for the Models (Confirmatory Factor Analyses)

\begin{tabular}{|c|c|c|c|c|c|c|c|c|}
\hline Model & $\chi^{2}$ & $d f$ & $p$ & $\chi^{2} / d f$ & NFI & TLI & CFI & RMSEA \\
\hline Perceptual dimension (1-factor model) & 121.40 & 35 & .00 & 3.47 & .63 & .60 & .69 & .14 \\
\hline Cognitive dimension (1-factor model) & 417.13 & 90 & .00 & 4.64 & .58 & .58 & .64 & .17 \\
\hline Emotional dimension (1-factor model) & 133.67 & 27 & .00 & 4.95 & .76 & .73 & .79 & .18 \\
\hline Communicative dimension (1-factor model) & 129.75 & 27 & .00 & 4.81 & .70 & .65 & .74 & .18 \\
\hline
\end{tabular}

Note. $\quad$ NFI $=$ normed fit index; TLI $=$ Tucker-Lewis index; CFI $=$ comparative fit index; RMSEA $=$ root-mean-square error of approximation.

Subsequently, the discriminant validity of the four dimensions was tested using CFAs. For the perceptual, emotional, and communicative dimensions, we compared a one-factor model (including all respective items) with a three-factor model (splitting into the three subdivisions). For the cognitive dimension, we compared a one-factor model with a four-factor model. As Table 4 reveals, the multifactor models showed better fit to the data than the respective one-factor models, confirming the discriminant validity of the four dimensions.

Cronbach's alphas for the four dimensions were all about .70, showing sufficient reliability. On the basis of these results, we built summated scales by adding the questionnaire items measuring the same dimension (cf. Vogt, 1993). Subsequently, these summated scales were divided by the number of items and used for the analyses in the remainder of the study. Intercorrelations and reliabilities of the four structural dimensions are shown in Table 5.

\section{Results}

To explore whether and how the four dimensions suggested by Eversmann (2004) contribute to the spectators' overall judgment of a theatrical event, we calculated a multiple regression analysis. The overall judgment of the event was regressed on the control variables (Model 1) and the four dimensions (Model 2). Tests for multicollinearity did not indicate problems.

Given that Model 1 was not significant (see Table 6), none of the control variables appeared to be relevant for spectators' overall judgment of a theatrical event. Moreover, according to Model 2, neither the communicative nor the perceptual dimension contributed to predict spectators' overall judgment. Instead, both the cognitive and emotional dimensions were significant predictors of spectators' overall judgment in theater. Interpreting the regression coefficients, the emotional dimension $(\beta=.478$, see Table 6$)$ seemed to be slightly more important than the cognitive dimension ( $\beta=.407)$. Together, these dimensions explained almost $70 \%$ of the variance in spectators' overall judgment of the theatrical event (adjusted $R^{2}=.68$ ).

\section{Discussion}

The aim of the present study was to identify determinants of visitors' overall judgment of a theatrical event. On the basis of Eversmann's (2004) model of the structural dimensions of a theatrical event, we developed a questionnaire for the purpose of the investigation. A study of 125 visitors of a production in a German community theater revealed that only the cognitive and emotional dimensions predicted the overall judgment, the emotional dimension being more important than the cognitive. However, this result might, in part, be caused by administering the questionnaires directly after the end of the performance. Eversmann stated that the emotional dimension is predominantly active during the performance, whereas the cognitive dimension (intellectually analyzing what has been seen) follows only some time after the applause has died. Hence, the outcome might have been different if the questionnaires had been administered later.

As this was the first attempt to predict visitors' overall judgment of a theatrical event on the basis of Eversmann's (2004) dimensions, some limitations of our study should be mentioned. First, because our measures had been developed for the purpose of the study, they should be elaborated in further studies. Although by far most scale reliabilities in our study turned out to be quite satisfying, further improvement is needed. In particular, the subdivisions "feeling of collectivity" (communicative dimension) and "the spectator's spontaneous physical reaction" (perceptual dimension) should be improved. Moreover, although the discriminant validity for the four dimensions was confirmed, the measurement validity for both the perceptual and communicative dimensions needs to be

Table 5

Intercorrelations Between the Constructs and Reliabilities (Dimensions)

\begin{tabular}{|c|c|c|c|c|c|c|c|}
\hline Scale & $M$ & $S D$ & $\begin{array}{l}\text { Perceptual } \\
\text { dimension }\end{array}$ & $\begin{array}{l}\text { Cognitive } \\
\text { dimension }\end{array}$ & $\begin{array}{l}\text { Emotional } \\
\text { dimension }\end{array}$ & $\begin{array}{l}\text { Communicative } \\
\text { dimension }\end{array}$ & $\begin{array}{c}\text { Overall } \\
\text { judgment }\end{array}$ \\
\hline Perceptual dimension & 3.67 & 0.61 & $(.76)$ & & & & \\
\hline Cognitive dimension & 3.42 & 0.69 & $.69^{* *}$ & $(.88)$ & & & \\
\hline Emotional dimension & 3.61 & 0.77 & $.81^{* *}$ & $.74^{* *}$ & $(.87)$ & & \\
\hline Communicative dimension & 2.89 & 0.73 & $.64^{* *}$ & $.62^{* *}$ & $.58^{* *}$ & $(.84)$ & \\
\hline Overall judgment & 3.90 & 0.96 & $.71^{* *}$ & $.76^{* * *}$ & $.78^{* *}$ & $.52^{* *}$ & $(.95)$ \\
\hline
\end{tabular}

Note. Reliabilities (Cronbach's alpha) shown on the diagonal within parentheses.

${ }^{*} p \leq .05$. **** $p \leq .01$. 
Table 6

Summary of Regression Analysis for Variables Predicting Visitors' Overall Judgment of a Theatrical Event $(N=125)$

\begin{tabular}{|c|c|c|c|c|c|c|}
\hline \multirow[b]{2}{*}{ Scale } & \multicolumn{3}{|c|}{ Model 1} & \multicolumn{3}{|c|}{ Model 2} \\
\hline & $B$ & $S E B$ & $\beta$ & $B$ & $S E B$ & $\beta$ \\
\hline \multicolumn{7}{|l|}{ Controls } \\
\hline Age & & $n s$ & & & $n s$ & \\
\hline Gender & & $n s$ & & & $n s$ & \\
\hline Education & & $n s$ & & & $n s$ & \\
\hline Prior experience in theater & & $n s$ & & & $n s$ & \\
\hline \multicolumn{7}{|l|}{ Antecedents } \\
\hline Cognitive dimension & & & & .570 & .107 & $.407^{* * * *}$ \\
\hline Emotional dimension & & & & .600 & .096 & $.478^{* * *}$ \\
\hline Perceptual dimension & & & & & $n s$ & \\
\hline Communicative dimension & & & & & $n s$ & \\
\hline$R^{2}$ & & .02 & & & .68 & \\
\hline Adjusted $R^{2}$ & & -.02 & & & .68 & \\
\hline$F(124)$ & & $0.457(n s)$ & & & $130.24^{* * *}$ & \\
\hline
\end{tabular}

**** $p \leq .001$.

improved. Second, our sample included the audience of only two performances of one theater production. Therefore, our results concerning the impact of the four structural dimensions of the theatrical experience on visitors' overall judgment cannot be generalized to "the" theatrical event. Rather, the results of our study are still preliminary. Third, the instrument developed in our study (see Table 1) cannot be generalized because it included questions that are suitable only for the particular play under study. However, we believe that the instrument can be adapted easily to other plays and other performances by following our example of formulating items.

Nevertheless, provided that the above limitations can be overcome and our results can be replicated in further research, our study reveals some interesting results. Although not intended to be a quantitative replication of Eversmann's (2004) study, our study seems to confirm some of the results that Eversmann found from his qualitative studies. First, his finding that the theatrical event consists of four distinct dimensions that are interrelated can be confirmed by our data. Although the intercorrelations of the scales are relatively high (see Table 5), the four dimensions can be clearly distinguished. Second, the subdivisions of both the emotional and cognitive dimensions as identified by Eversmann can be confirmed in our study. Third, although Eversmann did not investigate the relative importance of the four structural dimensions for the theatrical experience, he stated that the emotional dimension is "perhaps even more important than the cognitive operations" (p. 155). This assumption was confirmed by the regression analysis in our study.

Moreover, it may well be that Eversmann's (2004) findings on the four-dimensional structure of the theatrical event are more generalizable than he thought. His study was explicitly limited to theatrical peak experiences and involved predominantly experts in theater. In contrast, the results of our study suggest that the four-dimensional structure of the theatrical experience may be equally valid for the "average" experience of the "average" theater visitor. Although some visitors may have had peak experiences during the performance of The Dawns Here Are Quiet, this was not true for the majority of our participants. To the contrary, according to descriptive statistics, the participants of our study were mixed with regard to their overall judgment of the theatrical event $(M=$ $3.9, S D=0.96$; see Table 5). In addition, none of the controls we included in the study (i.e., participants' age, gender, education, and prior experience in theater) turned out to be significant, indicating that our results are equally valid for all of the included participants.

\section{References}

Allison, P. D. (2001). Missing data. Thousand Oaks, CA: Sage.

Arbuckle, J. L., \& Wothke, W. (2003). AMOS 4.0 user's guide. Chicago: Small-Waters Corporation.

Bentley, E. (1966). The life of the drama. London: Methuen.

Boerner, S., \& Jobst, J. (2008). The perception of artistic quality in opera: Results from a field study. Journal of New Music Research, 37, 233 245 .

Boorsma, M., \& van Maanen, H. (2003). View and review in the Netherlands: The role of theatre critics in the construction of audience experience. International Journal of Cultural Policy, 9, 319-335.

Csikszentmihalyi, M. (1991). Flow: The psychology of optimal experience. New York: Harper \& Row.

Csikszentmihalyi, M., \& Robinson, R. (1990). The art of seeing: An interpretation of the aesthetic encounter. Los Angeles: J. Paul Getty Museum/Getty Center for Education in the Arts.

DiMaggio, P., Useem, M., \& Brown, P. (1978). Audience studies of the performing arts and museums: A critical review. Washington, DC: National Endowment for the Arts.

Eversmann, P. (2004). The experience of the theatrical event. In V. A Cremona, P. Eversmann, H. van Maanen, W. Sauter, \& J. Tulloch (Eds.), Theatrical events: Borders, dynamics, frames (pp. 139-174). Amsterdam: Rodopi.

Graham, J. W., Cumsille, P. E., \& Elek-Fisk, E. (2003). Methods for handling missing data. In J. A. Schinka \& W. F. Velicer (Eds.), Research methods in psychology (pp. 87-114). New York: Wiley.

Jobst, J. (2007). Evaluation in öffentlichen Dienstleistungsorganisationen. Eine empirische Untersuchung zur Entstehung des Publikumsurteils im Musiktheater. (An empirical study on the audience judgment's development in opera.) University of Konstanz, Konstanz, Germany.

Johnson, D. M., \& Vidulich, R. N. (1956). Experimental manipulation of the halo effect. Journal of Applied Psychology, 40, 130-134. 
Kline, R. B. (2005). Principles and practice of structural equation modeling. New York: Guilford Press.

Konijn, E. A. (1991). What's on between the actor and his audience? Empirical analysis of emotion processes in the theatre. In G. D. Wilson (Ed.), Psychology and performing arts (pp. 59-75). Amsterdam: Swets \& Zeitlinger.

Konijn, E. A. (1999). Spotlight on spectators: Emotions in the theater. Discourse Processes, 28, 169-194.

Martin, J., \& Sauter, W. (1995). Understanding theatre: Performance analysis in theory and practice. Stockholm: Almqvist \& Wiksell International.

Pavis, P. (1988). Semiotik der Theaterrezeption. (Semiotics in the reception of theater.) Tübingen, Germany: Narr.

Perky, S. D. (1976). Effects of positive and negative audience response on actors' nonverbal performance behavior and on their attitudes. Bowling Green, OH: Bowling Green State University.

Renz, S. (2006). Evaluation in Nonprofit Organisationen. Eine empirische Untersuchung zur Rezeption der Aufführungsqualität im Musiktheater. (Evaluation in nonprofit organizations. An empirical investigation on the reception of performance quality in music theater.) University of Konstanz, Konstanz, Germany.

Reuband, K. (2005). Sterben die Opernbesucher aus? Eine Untersuchung zur sozialen Zusammensetzung des Opernpublikums im Zeitvergleich. In A. Klein \& T. Knubben (Eds.), Deutsches Jahrbuch für Kulturmanagement. (Do operagoers die out? An investigation on the social composition of the opera audience in chronological comparison. In A. Klein \& T. Knubben (Eds.), German yearbook for cultural management (pp. 123-138).) Baden-Baden, Germany: Nomos.

Roose, H., Waege, H., \& Agneessens, F. (2003). Respondent related correlates of response behaviour in audience research. Quality and Quantity, 37, 411-434.

Sargeant, A. (1997). Marketing the arts: Classification of U.K. theatre audiences. Journal of Nonprofit \& Public Sector Marketing, 5, 45-62.
Sauter, W. (2000). The theatrical event: Dynamics of performance and perception. Iowa City: University of Iowa Press.

Sauter, W. (2002). Who reacts when, how and upon what: From audience surveys to the theatrical event. Contemporary Theatre Review, 12(3), $115-129$.

Sauter, W., Kalvik, A., \& Isaksson, C. (1986). Das Publikum—Verständnis und Erlebnis von Theateraufführungen. In H. Schoenmakers (Ed.). The audience-Understanding and experience of theater performances. In $\mathrm{H}$. Schoenmakers (Ed.), Performance theory-Advances in reception and audience research (pp. 83-110). Utrecht, Germany: Instituut voor Theaterwetenschap.

Schafer, J. L., \& Graham, J. W. (2002). Missing data: Our view of the state of the art. Psychological Methods, 7, 147-177.

Schoenmakers, H., \& Tulloch, J. (2004). From audience research to the study of theatrical events: A shift in focus. In V. A. Cremona, P. Eversmann, H. van Maanen, W. Sauter, \& J. Tulloch (Eds.), Theatrical events: Borders, dynamics, frames (pp. 15-28). Amsterdam: Rodopi.

Scollen, R. J. (2008). Regional voices talk theatre: Audience development for the performing arts. International Journal of Nonprofit and Voluntary Sector Marketing, 13, 45-56.

Thompson, S. (2006). Audience responses to a live orchestral concert Musicae Scientiae, 10, 215-244.

Thorndike, E. L. (1920). A constant error in psychological ratings. Journal of Applied Psychology, 4, 25-29.

Vogt, W. P. (1993). Dictionary of statistics and methodology. Newbury Park, CA: Sage.

Zwingmann, C., Wirtz, M., Mueller, C., Koerber, J., \& Murken, S. (2006). Positive and negative religious coping in German breast cancer patients. Journal of Behavioral Medicine, 29, 533-547.

Received October 13, 2009 Revision received November 20, 2009 Accepted November 24, 2009

\section{ORDER FORM}

Start my 2010 subscription to Psychology of Aesthetics, Creativity, and the Arts ISSN: 1931-3896

$\begin{array}{ll}\$ 61.00 & \text { APA MEMBER/AFFILIATE } \\ \$ 92.00 & \text { INDIVIDUAL NONMEMBER } \\ \$ 375.00 & \text { INSTITUTION }\end{array}$

In DC and $M D$ add $6 \%$ sales tax

TOTAL AMOUNT DUE

Subscription orders must be prepaid. Subscriptions are on a calendar year basis only. Allow 4-6 weeks for delivery of the first issue. Call for international subscription rates.

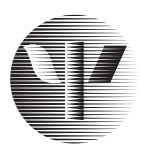

SEND THIS ORDER FORM TO

American Psychological Association

Subscriptions

750 First Street, NE

AMERICAN

ASSOCIATION

Washington, DC 20002-4242

Call 800-374-2721 or 202-336-5600

Fax 202-336-5568 :TDD/TTY 202-336-6123

For subscription information,

e-mail:subscriptions@apa.org
Check enclosed (make payable to APA)

Charge my: $\square$ Visa $\square$ MasterCard $\square$ American Express

Cardholder Name

Card No. Exp. Date

Signature (Required for Charge)

\section{Billing Address}

Street

City State Zip

Daytime Phone

E-mail

Mail To

Name

Address

City _ State _ Zip _

APA Member \# 